\title{
VIDEO CLIPS TO ENHANCE THE DEVELOPMENT OF THE STUDENTS' SPEAKING SKILL
}

\author{
Nurul Afifah ${ }^{1}$ \\ Universitas Baturaja \\ Dewi Lestari $^{2}$ \\ Universitas Baturaja \\ $\underline{\text { nurulafifah122@gmail.com }}{ }^{1}$ \\ Submit, 10-10-2019 Accepted, 21-12-2019 Publish, 22-12-2019
}

\begin{abstract}
The aimed of this study at investigating how the use of video clips could improve students' speaking skills of the class VIII D students of SMP NEGERI 1 Madang Suku III OKU TIMUR. This research was categorized into action research and implemented 2 cycles based on the class schedule. The researcher collaborated with the English teacher in this research. The sample of the study was 26 students of class VIII.D. The qualitative data are obtained through observation, interview, and documentation related to the teaching and learning process of speaking in the classroom including the techniques used by the teacher, the learning media and the classroom speaking activities. The findings showed that the use of video clip as the teaching media combined with the use of speaking activities and classroom English was proven to be effective to improve the students' speaking skills. It means that students' attention and increased their learning motivation. Through native speakers' talks, the students got appropriate models and could have better understanding how to use English in real situation so it opened their opportunity to practice speaking. The students who just gained 6.35 in the pre-test were able to increase their score up to 13.65 in the post-test. It indicated that they made a considerable improvement in some aspects of speaking skills such as fluency, pronunciation, grammar, vocabulary, and comprehension.
\end{abstract}

Keywords: enhance, development, video clips, speaking skill, improve

\section{INTRODUCTION}

Nowadays, English becomes very important in every field of life. Every people compete in this competitive world, many job and profession needs good applicant qualification that are capable in English in spoken even in written. Good 
speaking is crucial for everyday situation and career opportunities. Therefore, English is taught in to people all over the world as example in non-native speaker of English to prepare qualified people in the future.

In Indonesia English is yet considered as a difficult to learn. It didn't can be happen because there is speaking anxiety, low confidence when they have to speak in second language. However, good speaking is characterized by some factors of the most prominent one is fluency, but many students are hesitant and often make long pauses when they are speaking. These situations lead them to 'social phobia, which is the fear that they will act in a humiliating way and that other people will judge them negatively. Many second language students are able to perform well in reading, writing and listening but having problems to orally use the language confidently because of the presence of speaking anxiety.

Teaching English in Junior High school is to achieve communicative competence. Every student is hoped able to speak and communicate in English I their daily life, both written and spoken form. However, many teachers are not really aware of the problems in teaching speaking. Most of them tend to emphasize more on reading. They also tend to use textbook only in their English teaching. Appropriate English models to teach speaking are rarely presented. The teachers are the only models for students to learn pronunciation, fluency, accuracy and appropriateness in classroom setting because interactive media such as videos, movies, songs, realia, etc. are not optimally used in the teaching and learning process. The lack of media can cause boredom so that students do not feel interested in learning English and they cannot improve their language competence.

According to Richard \& Renandya (2002) a video as an extremely dense medium, one which incorporates a wide variety of visual. Therefore, it can video clips are recording segments of moving pictures and sound which can be played on the computer or television to present language forms and functions of language. By watching video clips, students can experience real-life situation and realistic models in elements and a great range of audio experiences in addition to spoken language. Furthermore, Anggeraini (2017) mentioned that youtube and online video can be used as of the activities to promote speaking. She suggested the conversation analysis from youtube that allows students to discuss the content and also evaluate it.

From the explanation above there is an article about the use of video clips, it was conducted by Hakim \& Akbar (2016) his research aimed to find out the effectiveness of video to improve students' speaking ability and to investigate the most improve aspect of speaking by using video. The calculation result of independent t-test on posttest scores showed that the significance value was lower than $0.05(0.000<0.05)$ which means the video treatment had improved the 
students' speaking ability. The score of effect size in large level (0.697) improved the students' speaking ability. Therefore, the use of video in teaching speaking solved one of speaking aspect that was the students' pronunciation. It is showed by the result between pretest score means and posttest score means from each aspect and pronunciation had biggest improvement with 0.67 differences from pretest to posttest. Because of that reasons it is best solution to use video in teaching English speaking in classroom.

In this research, aimed at investigating how the use of video clips could improve students' speaking skills. This was action research design. The improvement of speaking here was not only on one aspect of speaking but almost all aspect of speaking such as fluency, grammar, pronunciation, vocabulary and comprehension (Brown, 2001). The result of this research was the use of video clip as the teaching media combined with the use of speaking activities and classroom English was proven to be effective to improve the students' speaking skills.

\section{LITERATURE REVIEW}

\section{Video Clips}

Video clips provides great visual stimuli through the combination of illustrations, sounds, graphics, and texts and also the mixtures of sounds, pictures, mental images, perceptions, figures, texts, and others. It can engage the students to participate in teaching and learning process. Time duration made video clips different from other video. Hakim \& Akbar (2016) said that the video teaching technique focuses on the process of exposing the students to the example of situations and how to use particular expressions, and also how to pronounce words appropriately.

The popularity of the risen video clips can be searched by the students as young generation in several general sites such as YouTube, Yahoo Video, and Google Video. There are many videos to search and download. Videos can be downloaded from such links as Real English, BBC Learning English, 5 Minutes Video.com, Learning Upgrade, Let's Talk, School House Rock, Teacher Mario, Wildcatter Productions, etc for language teaching and learning, . The use of videos has grown since decades and provided positive factors in improving the teaching and learning process.

Furthermore, Harmer (2007) mentioned that there are three basic types of video that can be used in the classroom as learning media 1) off-air Programs, It includes program recorders from a television channel that can be engaging for students. Some off-air videos are extremely difficult for students to understand, especially where particular accents or colloquial language are used. The best programs are ones which can be used for a range of activities including prediction, 
teaching language, cross-cultural awareness or as stimuli for the students' own creativity, (2) Real-world Video, it's deals with featured films, exercise manuals, wildlife documentaries, comedy etc. In selecting the videos, teacher needs to make a choice based on how engaging and comprehensible the extract is likely to be, whether it has multi-use potential and the length of the extract that match to time allocation of activities in the classroom and (3) Language Learning Videos, it's are free-standing videos to accompany course books. The main advantage of these videos is that they have been designed for students at a particular level. Thus, they are comprehensible, designed to appeal to students' interests and multiuse as they can be used both for language study and a number of activities as well.

\section{The Important of Speaking Skill}

First, the ability of a person to produce the language by coordinating the speech organs such as the lips, tongue, teeth, vocal cords, larynx, pharynx, etc was called productive skill. Second, the purpose of producing language is to deliver ideas and experience therefore, the language can be receipt by the listener well. Third, being able to be directly and empirically observed means that the implementation of speaking can be directly heard or seen and empirically measured in the speaking process by looking at the correctness and effectiveness of the speaker (Harmer, 2007).

Renandya., et al (2002) said that speaking become difficult for foreign language learners because it need ability to use the language appropriately in social interaction. Furthermore, they said that speaking is one of the elements of communication.

\section{Types of Classroom Speaking Performance}

There are six similar categories apply to the kinds of oral production that students are expected to carry out in the classroom.

1. Imitative. Meaningful interaction in imitative focused on some particular element of language form. In imitative categories, such drilling offers the students opportunity to listen and orally to repeat certain strings of the language that may pose some linguistics it was called "a human tape recorder" speech.

2. Intensive. Intensive speaking performance is designed to practice some phonological or grammatical aspect of language. It can be self-initiated or can be a part of some pair work activity where the learners going over certain in forms of languages.

3. Responsive. The classroom activity provides question or comments on short replies to teacher based on students-initiated. These replies ado not extend into dialogues and sufficient. 
4. Transactional (Dialogue). Transactional language, negotiated nature happened in conversation when the purpose of conveying or exchanging.

Harmer (2007) suggests that there are six effective speaking activities students can do to improve their speaking skills. Those speaking activities are as follows:

1. Acting from a script. Students can be asked to act out scenes from plays in the classroom and sometimes make a video recording of the performance. It will encourage students to frequently perform in front of the class. The teacher has to give students time to rehearse the dialogues before they are asked to perform. When all students are practicing, the teacher can give attention to their intonation, stress, and speed. By giving students the practice before their final performance, as the result, acting out is both learning and a language producing activities.

2. Communication Games. Games are very effective to encourage many learners to make their interests and work sustainable. Useful and meaningful context can be created by the teacher through games. For instance, pictures games which are designed to provoke communication between students usually depend on an information gap so that one student has to talk to a partner in order to solve a puzzle, draw a picture (describe and draw), put things in the right order (describe and arrange) or find similarities and differences between the pictures.

3. Discussions. The difficulties of having discussion are that the students are shy and reluctant to share their opinion in front of the whole class and are not confident of the language they used to express their ideas. To avoid these difficulties, teachers can set up different types of discussion namely buzz groups, instant comment mini-activities, and formal debates.

4. Prepared Talks. Another activity to perform speaking is prepared talks where a student (or students) makes a presentation based on a certain topic. Because they are prepared, students should speak from notes rather than from a script to avoid these activities being more writing-like.

5. Questionnaire. Questionnaires ensure that both questioner and respondent have something to say to each other so that it is very useful to make students speak. Students can design questionnaires on any appropriate topic they are interested. Teacher can act as a resource and help students in designing it. The results can form the basis for discussions or prepared talks.

6. Simulation and Role play. Simulation and role play stimulate a real-life encounter and can be used to encourage general oral fluency. Students take on the role of a character different from themselves or with thought and feelings they do not necessarily share. 
Furthermore, there are some activities that promote the students' speaking so the students can practice and produce oral language well (Kayi, 2006).

1. Information Gap Activities. Information gap activities have some purposes such as collecting information and solve the problem. Information gap activities are effective because it encourages students to talk extensively in the target language.

2. Brainstorming. In brainstorming, students generate ideas in limited time based on particular context and given topics. This activity is effective to improve students' fluency since they are not criticized for their ideas. Students will be able to share their new idea freely.

3. Interviews. Conducting interviews with other people helps students to socialize and give them opportunities to practice speaking both inside and outside the classroom. Given selected topics, students should prepare their own interview questions to develop their creativity and critical thinking. After interviews, each student can present his/her study to the whole class.

4. Storytelling. Students can summarize a tale or story they heard from someone or create their own stories to tell their classmates. Storytelling fosters students' creativity and self-confidence. It also helps them to express their ideas in sequence format of the beginning, development, and ending of the story, including the characters and setting a story should have.

5. Reporting. Students are asked to read a newspaper and magazine or watching news program on the television before coming to the class. Then, they should report it to their classmates. To make a variety in the class, students can talk about their interesting experience in their daily life.

6. Picture describing. A way to make use of pictures in speaking activity is to provide students with pictures and make them describe the pictures. Students can work in groups and each group is given different pictures. After discussing the pictures, a spoke person from each group should describe the picture to the class. This activity fosters students' imagination and creativity as well as their public speaking ability.

According to Kayi (2006) presents some basics of teaching speaking in EFL setting. In the teaching and learning process of speaking, the learners should be able to

1. Use word and sentence stress, intonation patterns and the rythm of the target language.

2. Select appropriate words and sentences based on particular social setting, audience and situation.

3. Organize their thought in meaningful and logical sequence, and

4. Use the language quickly, confidently and fluently to express their ideas. 


\section{RESEARCH METHOD}

This research was categorized into action research. The procedure of the research can be shown below.

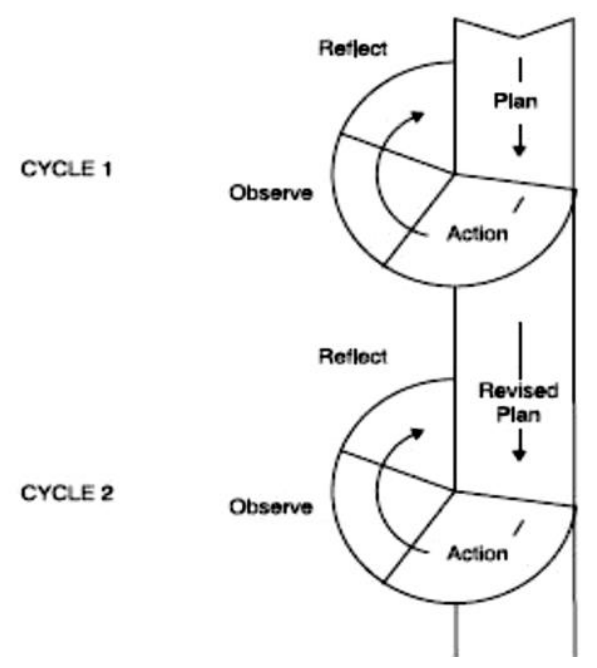

Research procedure by Kemmis and Tagart (1988) in Burns (2010) was used with some modification. The procedure consisted of four steps as presented below.

1. Reconnaissance. Observation and interview was done to identify the existing problems relate to the students' speaking skill. The researcher collaborates with the English teacher found out information related to the studentse ${ }^{\text {ee }}$ speaking skills. The result of this step was used as a basis for doing the second step, planning.

2. Planning. After doing observation in the reconnaissance step, the researcher made some plans to choose actions that were feasible to be implemented in the field. In this case, the researcher worked together with English teacher.

3. Implementing and Observing the Actions. In this step, the researcher implemented the four action plans that had been planned in the previous step in the learning teaching processes. The researcher and the teacher exchange places. The teacher conducted the actions in the classroom. The researcher observed and monitored the activities. Conversely, when the researcher acted as the class teacher, the class teacher acted as the observer.

4. Reflection. In this step, the researcher and the teacher evaluated the actions that were conducted in the implementation phase in the end of each class session. In evaluating the actions, the researcher and the teacher focused on the activities that were judge to be successful or less successful. The results of this step were used to determine whether the cycle was terminated or whether it was continued with a next cycle. 
In this study the data were involved into two types of data: qualitative and quantitative. The qualitative data are obtained through observation, interviews, and documentation related to the teacher techniques of speaking teaching and learning process, the media in learning used by the teacher in classroom and the classroom speaking activities. Meanwhile, the quantitative data are gained through speaking tasks, pretest, and post-test. Speaking tasks, pre-test and post-test are used to measure the improvement of students' speaking skills. The researcher worked collaboratively with the English teacher to conduct the speaking assessment.

1. Observations. Observations were used to discover about the activities in the classroom related the teaching and learning process, the ability of students' speaking skill, the students' speaking ability, the students' participation during the lesson, the students' understanding of the given materials, the methods and techniques used by the teacher, and about the given method to support teaching. Observation result put in the field notes. Field notes were useful to examine experience in order to understand it better by writing about it. It was used to record activities and situations during the research. By using field notes, the researcher could examine the data and deal with the problems of analysis.

2. Interviews. Interviews provide an opportunity to ask follow-up questions, reveal rich insights into the thinking of the participants and help explain why the participants made the choices they did. In the reconnaissance stages, the interviews focused on the teacher's perception of the students' English competence, the teacher techniques applied in the classroom, the materials given, facilities and media applied in the teaching and learning process, the students' perceptions of the English lesson, and the students' problems and difficulties in speaking and learning English. Furthermore, in the reflection stages, the interviews focused on students' opinion about the actions, the improvement of their speaking skills, their difficulties during the actions, the collaborator's opinion about the actions, the condition of the class, and the students' involvement during the lesson.

3. Documentations. Documentations involved taking photographs and videotape recording to monitor and evaluate the actions. Besides, the quantitative data are gained through speaking tasks, pretest, and post-test. Speaking tasks, pre-test and post-test were used to measure the improvement of students' speaking skills. The researcher worked collaboratively with the English teacher to conduct the speaking assessment.

There were two types of data in this research, qualitative and quantitative data. In qualitative data obtained from field notes, interview transcripts. The researcher used descriptive analysis suggested by Burns (1999) include five step 
the first, Assembling the data, the second Coding the data, third Comparing the data, fourth Building interpretation and fifth Reporting the outcomes.

In the quantitative data obtained from speaking performances were analyzed by using quantitative descriptive analysis. The students' speaking performances were assessed by using speaking rubric. The quantitative data were presented in the form of tables and mean scores. The means of pre-test and posttest were compared to know whether or not there was an increase in the students"e performances before and after the research treatment. The results of the speaking performances in each task were used to determine whether there were any improvements on the students' speaking skills.

\section{FINDING}

Beginning of the study, the researcher conducted an observation to the eighth grade students and did the observation of English teaching and learning process. In the Table below focus only in speaking problems:

Table 1. Speaking Problem

\begin{tabular}{|c|c|c|}
\hline No. & Code & Problems \\
\hline 1. & \multirow{8}{*}{$\mathbf{S}$} & $\begin{array}{l}\text { The students found difficulty in pronouncing many English } \\
\text { words and expression. }\end{array}$ \\
\hline 2. & & The students lacked vocabulary. \\
\hline 3. & & The students were not confident to speak English. \\
\hline 4. & & $\begin{array}{l}\text { The students had little opportunity to practice their English in } \\
\text { the class. }\end{array}$ \\
\hline 5. & & $\begin{array}{l}\text { The students could not carry out simple dialogues with adequate } \\
\text { fluency. }\end{array}$ \\
\hline 6. & & The students had low motivation in expressing their idea orally. \\
\hline 7. & & $\begin{array}{l}\text { The students had little opportunity to act out dialogues with the } \\
\text { other students. }\end{array}$ \\
\hline 8. & & $\begin{array}{l}\text { The students made many grammatical errors during the teaching } \\
\text { and learning process. }\end{array}$ \\
\hline \multirow{3}{*}{8.} & \multirow{3}{*}{$\mathbf{T}$} & The teaching of speaking was monotonous and boring. \\
\hline & & $\begin{array}{l}\text { The teaching techniques used by the teacher to present materials } \\
\text { were not attractive and interesting. }\end{array}$ \\
\hline & & The media did not support the materials. \\
\hline
\end{tabular}

Pre-test was also conducted to measure the students' initial speaking skills before implementing the action. The researcher and the English teacher became the raters to score the pre-test and the post-test which conducted in the beginning and the end of the research. This was to check the reliability of both the pre-test and post-test and also to fulfill the democratic validity of the research. 
Table 2 The Result of Pre Test

\begin{tabular}{llc}
\hline No. & Aspects of Speaking & Mean Score \\
\hline 1. & Fluency & 1.30 \\
\hline 2. & Pronunciation & 1.20 \\
\hline 3. & Accuracy & 1.16 \\
\hline 4. & Vocabulary & 1.10 \\
\hline 5. & Grammar & 1.03 \\
\hline
\end{tabular}

The data of the research are qualitative and quantitative. The quantitative data were analyzed by using quantitative descriptive analysis. The quantitative data were presented in the form of tables and mean scores. The students' speaking performances were assessed by using speaking rubric. The results of the speaking performances in each task were used to determine whether there were any improvements on the students' speaking skills. There were some preparation action and plans in order to make the actions as successful as possible. They were:

\section{Developing the Research Instruments}

Observation checklists, interview guidelines, speaking tests and speaking rubric were developed by researcher. When conducted the implementation of video clips and reflection, the observation conducted too. In planning stage and implementation of video clips, interviews did by the researcher to the students and the teacher. Furthermore, the speaking tests would be used to measure the students' speaking improvements and the speaking rubric would be used to assess and evaluate the students' speaking skills in pre-test, post-test and also the speaking practices.

\section{The Selecting of Materials}

The consideration of the material in teaching and learning material process based on syllabus and curriculum. The researcher and the teacher discussed materials which would be taught to meet the requirement of the curriculum. The materials including dialogues and monologues which should be mastered by the students. The topics which would be given were asking and giving attention and showing appreciation/compliment.

\section{Selecting the Teaching Media}

The media that would be used was video clips with consideration that by watching the video clips, the students would be able to see the authentic models of English and could get adequate input and examples of the target language beside 
that by using video clips as media in teaching and learning process interest the students to learn English and increase their motivation to Study English. Moreover, the students also could learn how to apply the language in real life contexts and daily conversations. The material of video clips were taken from you tube.

\section{Deciding the Teaching and Learning Activities}

Teaching and learning activities were combined with some communicative speaking activities such as describing picture and role-play to achieve the teaching and learning goal, i.e. students were able to communicate in English fluently, accurately, and appropriately.

\section{Findings of Cycle I}

The result of the implementation of video clips during teaching and learning process, based on observations and interviews the speaking assessments were also carried out to measure the improvements of the students' speaking skills. It described the increased of speaking skills including fluency, pronunciation and grammatical accuracy, vocabulary. The table below presents the students means score of speaking aspect during the teaching and learning process.

Table 3 The Students' Mean Score of each Aspect in Cycle I

\begin{tabular}{llll}
\hline \multirow{2}{*}{ Speaking aspect } & \multicolumn{3}{c}{ Mean score } \\
\cline { 2 - 4 } & Task 1 & Task 2 & Gain score \\
\hline Fluency & 2.12 & 2.25 & 0.20 \\
\hline Pronunciation & 1.30 & 1.77 & 0.45 \\
\hline Grammar & 1.40 & 1.56 & 0.30 \\
\hline Vocabulary & 1.36 & 1.75 & 0.40 \\
\hline Comprehension & 1.30 & 1.52 & 0.21 \\
\hline
\end{tabular}

The researcher and the collaborator conclude findings of cycle 1. There were some successful and unsuccessful actions. They were described in Table 4 
Table 4. Succesfull and Unsuccessful Actions

\begin{tabular}{|c|c|}
\hline \multirow[t]{2}{*}{ No. } & FINDINGS in Cycle 1 \\
\hline & Unsuccessful actions \\
\hline 1. & $\begin{array}{l}\text { The implementation of video clips } \\
\text { to enhance and provide appropriate } \\
\text { to quite confusing since the video } \\
\text { models of English for the students } \\
\text { and real context of communication } \\
\text { separately. } \\
\text { were successfully achieved. }\end{array}$ \\
\hline 2. & $\begin{array}{lll}\text { Students could understand the } & \text { There were technical problems } \\
\text { materials easily through video } & \begin{array}{l}\text { during the preparation of the video } \\
\text { were not really audible. Therefore, } \\
\text { watching } \\
\text { the preparation was quite time } \\
\text { consuming. }\end{array} \\
\end{array}$ \\
\hline 3. & $\begin{array}{l}\text { Students have wide opportunities to } \\
\text { practice speaking ability in real mispronunciation in some words. } \\
\text { situation by using communicative } \\
\text { speaking activities }\end{array}$ \\
\hline 4. & $\begin{array}{l}\text { By using classroom activities, it } \text { In practicing the speaking, some } \\
\text { enhances Students' motivation and students still faced difficulties when } \\
\text { interest since the classroom they want to express their ideas; } \\
\text { activities were more varied and they still confuse to choose } \\
\text { interesting. }\end{array}$ \\
\hline 5. & $\begin{array}{l}\text { When practice some students could Some students still faced error in } \\
\text { speaking fluently, The students use grammatical accuracy } \\
\text { could pronounce words and use } \\
\text { words and intonation correctly. }\end{array}$ \\
\hline 6. & $\begin{array}{l}\text { Students speak fluently and - } \\
\text { confidently when they perform in } \\
\text { front of the class. }\end{array}$ \\
\hline
\end{tabular}

It can be seen from the table the problems and the progress faced by the students. For the next cycle the researcher and the teacher decided to implement some actions to enhance and enhance the students speaking skill.

\section{Findings of Cycle II}

After reflecting on the implemented actions and scoring the students' speaking performance, the researcher and the collaborator concluded the findings of cycle II. There were some improvements during the implementation in this cycle. They were described in Table 5 
Table 5 Some Improvements During the Implementation

\section{No. Improvements}

1. The goals of using video clips as teaching media to provide appropriate models of English for students and to present the real context of communication were successfully achieved

2. Students found the video clips interesting and easier to comprehend

3. Students found the video clips interesting and easier to comprehend

4. Students could understand the materials easily through video watching

5. In communicative activities, the students practice their speaking skill in real situation

6. The motivation and interest of Students improved in studying English

7. The pronunciation of the students improved, they were able to pronounce the words in correct intonation.

8. The students more confident

9. The students' grammar and comprehension

The result of the students means score can be seen from the table below.

Table 6: The Mean Scores of Student Performance in Cycle II

Table 6 The Mean Scores of Student Performance in Cycle II

\begin{tabular}{llll}
\hline \multirow{2}{*}{ Speaking aspect } & \multicolumn{3}{c}{ Mean score } \\
\cline { 2 - 4 } & Task 1 & Task 2 & Gain score \\
\hline Fluency & 2.63 & 2.70 & 0.13 \\
\hline Pronunciation & 2.50 & 2.75 & 0.20 \\
\hline Grammar & 2.40 & 2.60 & 0.19 \\
\hline Vocabulary & 2.65 & 2.75 & 0.16 \\
\hline Comprehension & 2.30 & 2.40 & 0.18 \\
\hline
\end{tabular}

Based on the discussion between researcher and teacher as collaborator, based on the findings of cycle II that all action improves the students' speaking skill and the objective of the research was achieved both of them agreed to end the research in this cycle.

\section{DISCUSSION}

As description before, the using of video clips and the supplementary actions were successful in improving the students speaking skill. The findings were from the observation and the interviews with the English teacher and the students during the process of the research. Pre-test was done on 23th of July, 
2019 and the post-test on 19th of August 2019. The following table described the comparison between pre-test and post-test score.

Table 7 The Comparison between the Pre-Test and Post-Test Result

\begin{tabular}{ccc}
\hline Score & Pre-test & Post-test \\
\hline Mean & 6.35 & 13.65 \\
\hline
\end{tabular}

It can be seen from the table, there were significant improving the students' speaking skill. The students' score from 6.35 in pre-test could be increase to 13.65. It indicate the use of video clips in learning process improve the students' speaking ability and it's prove that the use of video clips was effective to improve their speaking ability, besides, it's also described the use of video clips enhance the development of the students' speaking skill. The summary of the improvement of the students' speaking skill can be seen from the following table:

Table 8 Students' speaking Skill Before and After the Use of Video Clips

\begin{tabular}{|c|c|c|c|}
\hline $\begin{array}{l}\text { Aspect of } \\
\text { speaking }\end{array}$ & Pre-condition & Cycle I & Cycle II \\
\hline Fluency & $\begin{array}{l}\text { The students less } \\
\text { of confidence, } \\
\text { because they were } \\
\text { afraid of making } \\
\text { mistakes when } \\
\text { performed in front } \\
\text { of the class }\end{array}$ & $\begin{array}{l}\text { Most of the } \\
\text { students could } \\
\text { join speaking } \\
\text { class but they still } \\
\text { felt hesitate, } \\
\text { sometimes pauses, } \\
\text { and still less } \\
\text { confidence to } \\
\text { speak English }\end{array}$ & $\begin{array}{l}\text { Most of the } \\
\text { students easy to } \\
\text { express their idea, } \\
\text { opinion and they } \\
\text { did not afraid of } \\
\text { making mistake } \\
\text { it's mean that the } \\
\text { students made the } \\
\text { progress in } \\
\text { speaking fluency. }\end{array}$ \\
\hline Grammar & $\begin{array}{l}\text { The students made } \\
\text { many grammatical } \\
\text { errors frequently, } \\
\text { and they did not } \\
\text { have confidence } \\
\text { control of the } \\
\text { grammar. }\end{array}$ & $\begin{array}{l}\text { The students have } \\
\text { improvement } \\
\text { progress in did the } \\
\text { task. In third task. } \\
\text { Some of them } \\
\text { made errors of } \\
\text { grammar and } \\
\text { word order }\end{array}$ & $\begin{array}{l}\text { Most of the } \\
\text { students made } \\
\text { improvement in } \\
\text { grammar although } \\
\text { some of them still } \\
\text { made error in } \\
\text { grammar. }\end{array}$ \\
\hline Pronunciation & $\begin{array}{l}\text { The students } \\
\text { frequently } \\
\text { mispronounced } \\
\text { words, intonation } \\
\text { and stress pattern }\end{array}$ & $\begin{array}{l}\text { Most of the } \\
\text { students were able } \\
\text { to pronounce } \\
\text { words, intonation } \\
\text { but they still }\end{array}$ & $\begin{array}{l}\text { Most of the } \\
\text { students made } \\
\text { progress in } \\
\text { pronunciation. } \\
\text { Most of the }\end{array}$ \\
\hline
\end{tabular}




\begin{tabular}{|c|c|c|c|}
\hline & $\begin{array}{l}\text { that made the } \\
\text { speech strange and } \\
\text { unintelligent }\end{array}$ & $\begin{array}{l}\text { confused to use } \\
\text { stress pattern }\end{array}$ & $\begin{array}{l}\text { students could } \\
\text { pronounce words } \\
\text { correctly, } \\
\text { appropriate } \\
\text { intonation and } \\
\text { stress } \\
\text { patterns. }\end{array}$ \\
\hline Vocabulary & $\begin{array}{l}\text { Most of the } \\
\text { students have } \\
\text { limited vocabulary } \\
\text { and misused the } \\
\text { vocabulary }\end{array}$ & $\begin{array}{l}\text { The students made } \\
\text { slow } \\
\text { Improvements. } \\
\text { They still } \\
\text { frequently } \\
\text { used wrong words } \\
\text { and have limited } \\
\text { vocabulary }\end{array}$ & $\begin{array}{l}\text { The students have } \\
\text { increased } \\
\text { progress in } \\
\text { vocabulary. }\end{array}$ \\
\hline Comprehension & $\begin{array}{l}\text { The students } \\
\text { difficult to } \\
\text { understand the } \\
\text { instruction from } \\
\text { the teacher when } \\
\text { the teacher used } \\
\text { English. They } \\
\text { could understand } \\
\text { very simple } \\
\text { questions and } \\
\text { explanation in } \\
\text { slowed speech }\end{array}$ & $\begin{array}{l}\text { Most of the } \\
\text { students could the } \\
\text { conversation. } \\
\text {. }\end{array}$ & $\begin{array}{l}\text { The students' } \\
\text { comprehension is } \\
\text { improved. Most } \\
\text { of them could } \\
\text { understand the } \\
\text { conversation } \\
\text { within the range } \\
\text { of their } \\
\text { experience. }\end{array}$ \\
\hline
\end{tabular}

From the result of the research, the using of video clips there are significant improvement of speaking skill. it accordance of the advantages of using video clips in learning, the first, Video clips provide important visual stimuli for language production and practice such as settings, actions, emotions, expressions, gestures, illustrations, visuals, pictures, perceptions, mental images, figures, impressions, likenesses, cartoons, charts, graphs, colors, replicas, and reproductions (Harmer, 2007; Intajuck, (2010); Canning and Wilson, 2000). By using video clips in classroom, the students are able to see audiovisual of the native speaker, the students are not only hear the language but also can see it. Furthermore, the students can see paralinguistic cues of speakers and it automatically enhances the meaning. Through paralinguistic features help students interpret the text deeply. For example, intonation of an utterance which is matched with facial expressions can differentiate the meanings of messages. 
Furthermore, According to Intajuck (2010) positive effects the use of video clips are provide interest and motivate of the students to accompany audio or written inputs, thereby aiding comprehension and production of foreign language input and output. One of the greatest strengths in language teaching is the ability to communicate with viewers on an emotional communication, as well as a cognitive level. Due to the ability to reach viewers' emotions, the video can have a strong positive effect on both motivation and affective learning. Through video can generate prediction, speculation and a chance to activate background schemata when viewing a visual scene reenacted because it provides visual stimuli such as the environment and situation (Canning, 2000) Many advantages the use of video such as help the non-native speakers understand stress pattern, see the body movement and speech rhythm in second language discourse that can be found when use authentic language and speed of speech in various situations.

\section{CONCLUSION}

Most of the students made some significant improvements on the aspects of speaking skills such as fluency, pronunciation, grammatical, vocabulary and comprehension. The improvement of students' speaking skill. The improvements occur in all aspects of speaking including fluency, accuracy, pronunciation, and vocabulary. It can be seen from the increase of pre-test score and post-test.

\section{REFERENCES}

Anggeraini, Y. (2017). Technology and Character Education In EFL Classroom. In Unnes-Teflin National Seminar

Brown, H.,D. (2001). Teaching by Principles: An Interactive Approach to Language Pedagogy. New York: Pearson Education

Canning, C. (2000). Practical Aspects of Using Video in the Foreign Language Classroom. The Internet TESL Journal, 4(1)

Canning, C \& Wilson. A. (2000). Practical Aspects of Using Video in the Foreign Language Classroom. The Internet TESL Journal, 4(11)

Hakim, M., I \& Ali, A. (2016). The use of video in teaching English speaking" (a quasi-experimental research in senior High School in Sukabumi). Journal of English and education, 4 (2), 44-48.

Harmer, J. (2007). The Practice of English Language Teaching. 3rd ed. Cambridge: Pearson Education.

Intajuck, Y. (2019). Maximalizing the Utilization of Video in the EFL/ESL Classroom. Retrieved on 23rd September 2019 from www.ralphsesljunction.com/usingvideoclips.

Kayi, H. (2006). Teaching Speaking: Activities to Promote Speaking in a Second Language. The Internet TESL Journal, 12(11)

Richards, J. C \& Renandya, W. A. (2002). Methodology in Language Teaching: An Anthology of Current Practice. Cambridge University Press: New York 